\title{
Religious Freedom and Diversity in a Comparative European Perspective
}

\author{
Olivier Roy \\ Robert Schuman Center for Advanced Studies, Florence \\ Contact: Olivier.Roy@eui.eu
}

The Balkan states are relatively young nation-states that achieved independence through a succession of bloody wars, either civil (the dissolution of Yugoslavia after the fall of Communism), regional (the Balkan wars at the turn of the 19th-20th century) and/or global (the end of two world wars). All of them now claim, or aspire, to be modern, democratic and secular states, and are on their way to integration with the more 'mature' Western European counterparts. The debate about progress of democratization and their capacities to integrate into the EU has brought to the fore issues of political 'maturity' in terms of good governance, and the protection of minorities and other human rights. The harsh and sometimes bloody legacy of nation- and state-formation, amidst plural ethno-religious divisions, seemed to be an impediment for achieving the status of democratic states. Religious and ethnic tensions were seen as particularly worrying. Specifically, these states had to face simultaneously at least two major constraints: on the one hand, guaranteeing religious freedom and equal treatment for all citizens; on the other hand, holding on to the religion of the nation, which had kept the nation intact when the state disappeared. After 1990, the challenge then was to set up new institutional compromises and suitable balances that could combine (1) religious freedom, (2) state neutrality and (3) the majoritarian or 'traditional' basis of nationhood. ${ }^{1}$

\section{Democratic Freedoms and Historical Legacies}

The articles in this special issue show that historical legacies are not always harmful. There are plenty of data here to demonstrate that certain legacies of homogenous nation-state-building and states' sticking to majoritarian biases and religious symbols hamper the easy introduction of democratic standards. Yet, what is probably neglected is that the formalization of, and even more so habitation to, new values of religious freedom and state neutrality have never been an easy or 
fast process also elsewhere in the more 'mature' democratic world. Post-communist Balkan states have managed to create new institutional balances and a more equal playing field for all religious communities with relative ease when compared to the lengthier and still contested process in Western European states. Not only has the formal challenge of legalizing religious freedom and state neutrality been quite successfully fulfilled, but the historical past has seemingly provided these states with suitable experiences to accommodate various religious groups, especially Muslims.

After the fall of Communism, all the countries under analysis demonstrate ample institutional attempts to expand the range of religious freedoms and the state's equal treatment of all denominations, including the Islamic community. Cases show difficulties in adjusting to new standards, but there are no real cases of religious discrimination. Even when the state, as in most Christian Orthodox polities, extend formal and informal privileges to the dominant religion and to its church, these favors go hand in hand with the institutionalization of an equal playing field for all. Muslim-majority Albania is a particularly interesting case, which has consensually embraced the ideal of an equidistant state towards all religious views, as the most suitable template to deal with plurality. ${ }^{2}$ The next state that has paid 'extra' attention to management of plurality is post-Dayton Bosnia. Here, the post-war legal framework has endorsed multiple guarantees of religious freedom and equality for all the constituent communities. ${ }^{3}$ PostCommunist Bulgaria has recognized the traditional role of the Bulgarian Orthodox Church, but also provided ample individual and collective guarantees to diverse sections of its Muslim community. ${ }^{4}$ At the other end of the spectrum is Turkey, where the Sunni-majority, embedded into the governing state structures, dominates the religious life of the country. That the country is run by a Sunni-rooted governing majority for over a decade now, did not help to even out the legal/institutional disparity among different religious groups and their claims. ${ }^{5}$

Nonetheless, existing tensions are more about ethnic minorities than religious minorities. In other words, tensions are not about the religious practices of these minorities, but about their sociopolitical claims and/or their links and loyalty to other political entities. This is an important difference even when compared to the effects of open model of managing plurality in India, where ongoing attacks randomly target the practices and symbols of 'others'. But, this is also 
different from Western Europe where current clashes involving populations with a migrant background concentrate more and more on their religious practices such as the veil, prayers, hallal food and/or desecration of sacred places. In this sense the Balkan states, proved better suited to deal with the plurality of religious practices in the public sphere, specifically Muslim practices, than their Western European counterparts.

New legal standards of freedom and equality have helped. But, obviously there is much more to it. The main reason is that this 'coexistence' of plurality is the result of a long historical process of dealing with tensions, exchanges and coexistence that have made Islam a 'local' religion, the same way that Protestantism became a 'local' religion after the traumatic break-up of the unified Catholic world by the Lutheran Reformation, particularly in Germany. To sum up, tensions about religious differences between Albanians, Serbs, Bosniaks, Turks or Bulgarians do not concern the practice of their respective religion. These practices are familiar to each other: there is a social knowledge of practices of other religions that is not found in Western Europe. Put differently, the other is still an 'other' but a more familiar one.

\section{Equality, Identity and Faith}

Nevertheless freedom of religion does not always mean equality between religions, and this holds true both in the Balkans and in Western Europe, irrespective of the wording of the various constitutions. Most countries have a dominant religion, and a dominant church, especially in Christian Orthodox countries. The church enjoys political privileges, is associated with national celebrations, and is conferred a special socio-political role. Contrary to what may happen in Greece or Turkey through mandatory religious teaching at school, however, such privileges do not necessarily amount to a systematic effort to encourage individuals' particular religious practices or commitment to a church. Privileges awarded to a specific church are more a way to stress cohesive national identity than to propagate faith and participation in weekly mass. The emphasis on an official religion is more a matter of identity, than faith. 
In a sense we can see a rapprochement of Balkan states with Western Europe here. Even when there is no an official state or a national religion, the states under analysis have attempted to organize and watch over collective expressions of national identities and their intimate connections to specific churches. The European Court of Human Rights (ECtHR) and the European Commission, meanwhile, have regularly accused specific Catholic Orthodox countries for acts of religious discrimination; for example, to remedy discrimination, the ECtHR requested Greece to remove religion from identification cards. However, recent ECtHR decisions have endorsed the states' right to recognize one religion as an expression of a national identity or culture, by allowing for instance Italian schools to display the crucifix but not symbols of other religions. In doing so, the ECtHR recognizes the concept of a dominant national culture and condones the concept of multiple secularities. In other words, the state's adoption of a dominant culture does not clash with secularism, but is a form of different secularisms. The ECtHR's approach also hinges on the contingent, home-grown virtues of different models. Indeed, there is no 'best' template of secularism to follow, be it the US 'wall of separation', French 'laïcité' or the open-negotiated Indian arrangements. Instead, different states developed various historicaland context-specific interpretations of secularism, which reverberate the religious and political necessities of time and place. The Balkan states are no exception. All cases here provide ample evidence of contingent models of secularisms coming of age. From Albania, to Bosnia, to Bulgaria and Turkey, democratizing polities have opted for different arrangements to accommodate and regulate their respective Muslim communities in the context of religious diversity.

\section{State Supervision and Bureaucratization of Religion}

Another commonality between the Balkan states is that they all established some sort of state supervision of the religious sphere, most often by organizing, recognizing, and collaborating with one nationwide institution representing the respective religious community. Specifically, all countries analyzed privilege the role of hierarchical Muslim organizations endowed with the sole authority in administering all administrative and spiritual matters concerning the Muslim community. What is often a legacy of previous non-democratic regimes, this 'bureaucratization' 
of religion seems at odds with a liberal-democratic approach that would explicitly prohibit state interference in the way religions organize and run themselves. Here too broad precepts of liberal theories might not be the best lens to analyze practical institutional solutions for coping with religious plurality in different contexts. States often face the mounting challenge of accomodating various religious claims and hands-off neutrality does not suffice to arbiter such claims or ensure that they indeed adhere to a common denominator of common good - be it peace, democracy, security, safety and a plural home for all. One should also acknowledge that liberal Western European states are on the path to pushing for the establishment of staterecognized representative Islamic organizations. In these cases, this is rarely a legacy of the past, but more a practical institutional solution to thwart uncontrolled diffusion of radical Islamic groups and bring them into the fold of the state. In any case, it amounts to a new kind of compromise between the state and an incoming religious community. It opens up the possibility to negotiate with religious movements which do not feel part of the historical compromises that different states have, more or less painfully, set up among themselves and the dominant religious groups, from Concordat to laïcité and to established churches.

From the Balkans to Western Europe, we can thus witness the development of new forms of state intervention in the management of Islamic communities and religious diversity more broadly. The difference between Western Europe and the Balkans is that the former is striving to establish this new kind of control under the pressure of recent immigration and the current events linked with Islamic radicalism, without a long-term perspective and with few historical precedents. In contrast, Balkan countries have, since their foundation in the $18^{\text {th }}$ and $19^{\text {th }}$ century, emerged as multi-religious and multi-ethnic polities, which confronted them early on with the question of accommodating Muslim communities within their plural societies. Given that they confronted the 'problem' at least one century ahead of their European counterparts, they offer some useful guidance on models for governing Islam in plural contexts, with all their faults and attributes. In this sense, a European 'local' Islam already exists and that is in the Balkans.

\section{Notes on Contributors}


Olivier Roy is Head of the Mediterranean Program at the Robert Schuman Center for Advanced Studies, Florence. He is the author of numerous books on topics related to Political Islam, the Middle East, Islam in the West and comparative religions.

\footnotetext{
${ }^{1}$ See A. Elbasani, 'Governing Islam in plural societies: religious freedom, state neutrality and traditional heritage', Journal of Balkan and Near Eastern Studies, forthcoming.

${ }^{2}$ A. Elbasani and A. Puto, 'Contingent interpretations of laïcité in Albania', Journal of Balkan and Near Eastern Studies, forthcoming.

${ }^{3}$ A. Alibašić and N. Begović, 'Reframing relations between state and religion in post-war Bosnia: learning to be free!', Journal of Balkan and Near Eastern Studies, forthcoming.

${ }^{4}$ E. Ivanova, Islam, 'State and society in Bulgaria: new freedoms, old attitudes?' Journal of Balkan and Near Eastern Studies, forthcoming.

${ }^{5}$ E. Tombuş and B. Aygenç, '(Post-)Kemalist secularism in Turkey’, Journal of Balkan and Near Eastern Studies, forthcoming.
} 